Article

\title{
An Ecolabel for the World Heritage Brand? Developing a Climate Communication Recognition Scheme for Heritage Sites
}

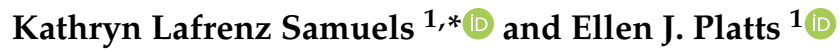 \\ Department of Anthropology, University of Maryland, College Park, MD 20742, USA; \\ ejplatts@terpmail.umd.edu \\ * Correspondence: lafrenzs@umd.edu
}

Received: 30 January 2020; Accepted: 3 March 2020; Published: 5 March 2020

check for updates

\begin{abstract}
This study develops a climate communication recognition scheme (CCRS) for United Nations Educational, Scientific and Cultural Organization (UNESCO) World Heritage Sites (WHS), in order to explore the communicative power of heritage to mobilize stakeholders around climate change. We present this scheme with the aim to influence site management and tourist decision-making by increasing climate awareness at heritage sites and among visitors and encouraging the incorporation of carbon management into heritage site management. Given the deficits and dysfunction in international governance for climate mitigation and inspired by transnational environmental governance tools such as ecolabels and environmental product information schemes, we offer "climate communication recognition schemes" as a corollary tool for transnational climate governance and communication. We assess and develop four dimensions for the CCRS, featuring 50 WHS: carbon footprint analysis, narrative potential, sustainability practices, and the impacts of climate change on heritage resources. In our development of a CCRS, this study builds on the "branding" value and recognition of UNESCO World Heritage, set against the backdrop of increasing tourism-including the projected doubling of international air travel in the next 15-20 years-and the implications of this growth for climate change. The CCRS, titled Climate Footprints of Heritage Tourism, is available online as an ArcGIS StoryMap.
\end{abstract}

Keywords: climate change; climate communication; mitigation; adaptation; World Heritage; heritage tourism; carbon footprint; carbon management; ecolabel; environmental product information scheme; transnational governance

\section{Introduction}

Heritage tourism represents an important nexus in which cultural heritage resources and anthropogenic climate change intersect. This is especially the case for efforts pursuing climate mitigation and climate communication. Tourism is a major contributor to greenhouse gas emissions, and the tourism industry will require broad changes to operations in order to mitigate climate change [1-4]. In 2005, the tourism industry (including transport, accommodation, and activities) was estimated to contribute $5 \%$ of global anthropogenic carbon dioxide emissions (with aviation transport accounting for $40 \%$ of this amount, car transport for 32\%, and accommodation for $21 \%$ ) [5-7]. By 2013, tourism accounted for $8 \%$ of global greenhouse gas emissions, and previous reports may have underestimated the contribution [8]. Moreover, tourism is only expected to grow, with carbon dioxide emissions predicted to increase 135\% between 2005 and 2035 [5-7] and international air travel projected to double in the next 15-20 years [9]. Scholars in tourism studies have turned a spotlight on global climate change $[2,3,10,11]$, including increasingly sophisticated accounts of the carbon systems in tourism $[12,13]$ and "carbon management" to mitigate the impacts of climate change from 
tourism [1]. The impetus of our study dovetails with current research in tourism studies on climate change, but cultural heritage has rarely been the focus of such studies.

Heritage sites and resources feed the trends in the diversification and geographic expansion of tourism. Indeed, the case of heritage tourism is especially urgent, since according to some estimates it accounts for approximately half of all tourism [5,14], and it contributes to the destruction of the resources on which it is based, both presently and, considering projected climate impacts, in the future. Moreover, taking into account that heritage tourism is one of the principle means for pursuing economic development through heritage resources, the detrimental impacts of heritage tourism on heritage resources in light of climate change thus raises the question of whether the use of heritage tourism for sustainable development is viable.

At the same time, World Heritage has also been picked up by climate scientists and activists as a flashpoint for taking action on global climate change, given the impacts that climate change will have on well-known heritage sites beloved by many [15,16]. The Great Barrier Reef has attracted particular attention, as its status as a World Heritage Site (subject to international treaty law) has been leveraged to bring the Australian Government to account for its tepid response to climate change mitigation $[17,18]$. An explicit focus on cultural heritage in climate action and climate communication can raise in sharp relief the anthropogenic and long-term character of global climate change. Yet, as the link between global climate change and loss of WHS is made stronger in the public imagination, trends in what is called 'last chance tourism' [19-22] suggest that WHS impacted by climate change will attract increasing numbers of visitors, to witness the WHS 'before it is gone' or irreparably changed. 'Last chance tourism' often has the paradoxical effect of hastening the deterioration of the site in question, for example from increasing pollution and greenhouse gas emissions from Antarctic cruise tourism [23] or the carbon costs associated with polar bear tourism in Churchill, Canada [24].

National governments and local development initiatives often pursue inscription of sites on the UNESCO World Heritage List because of its performance in attracting international tourism (the most "costly" of tourism carbon footprints) [25-29]. Indeed, the UNESCO World Heritage List has exploded to over 1100 properties and counting, overwhelming the List's original conservation mandate as national governments seek to attract foreign tourism revenue and foster economic growth through the World Heritage "brand." The branding function of World Heritage is powerful and increasingly central to motivations for inscription [30-33].

WHS around the globe hold a special resonance for the communities residing within or nearby the sites, the governments that nominate the sites at much expenditure, and the tourists and other visitors who choose a World Heritage Site as a destination worth visiting. As the world's cultural treasures, WHS elicit concern for conservation and sustainability, coupled with a well-known brand recognition. These two facets of World Heritage-conservation and branding-provide an excellent vehicle for drawing public awareness and action to the problem of global climate change. Further, while previous sustainability-oriented work on WHS has focused on "sustainable tourism" [34-36], social sustainability [37], or site sustainability [38], scholarship on the sustainability of WHS vis-à-vis climate change remains incipient, especially with respect to the contributions of World Heritage Site facilities and tourism to the production of greenhouse gases and to incorporating carbon management as part of site management and heritage management more broadly.

The growth of the World Heritage List to over 1100 sites also tracks a sea change in heritage management in global contexts more broadly, from management models built around preservation and conservation to those built around economic development [39,40]. Conservation and development have been two sides of the same coin since at least the 1940s, with the rise of international cooperation over heritage resources. However, development is increasingly the raison d'être of heritage management globally, as state and community interest in using cultural heritage for economic development has grown, and international development circles have adopted cultural heritage as a socially-responsive approach to development attuned to sustainability and human capabilities. 
In the following we detail the development of what we call a "climate communication recognition scheme" (CCRS) for UNESCO WHS, as a tool for using heritage sites to communicate the drivers and impacts of anthropogenic climate change. The CCRS, titled Climate Footprints of Heritage Tourism, is available online as an ArcGIS StoryMap at http://www.heritageofclimate.com [41]. While considerations of climate change are increasingly being incorporated into heritage management practices, including within WHS nominations, the focus remains on climate-related threats and impacts to heritage resources, rather than the contributions of heritage sites as drivers of anthropogenic climate change-for example from site infrastructure, tourism, and land use. We argue for the value of a more holistic response in heritage management to the challenges of climate change, one that takes into account impacts alongside fostering adaptive capacity, integrating carbon management practices for mitigation, and communicating climate change through the public platforms afforded by heritage resources. Given the relative lack of attention paid to mitigation and climate communication, we focus our efforts in the CCRS especially on these two dimensions, but impacts and adaptation are also represented.

This holistic approach that we advocate is further reflected in our decision to conceive of the category of CCRS. We describe CCRS as an extension or elaboration of ecolabels. "Ecolabels" assign labels to consumer goods (for example, organic and fair trade certification of foods) for the purpose of communicating the sustainability of a product, but they tend to be one-dimensional and quantitatively driven. As discussed below, a CCRS expands on ecolabels to provide a more holistic recognition scheme, and one that is specifically attuned to communicating climate change.

While a CCRS could be developed for any heritage site, in this study we focus on WHS to leverage the brand recognition of World Heritage-as global heritage conservator-into a "product" or platform for developing the CCRS. The value of a CCRS for heritage resources is that it offers another frontline for climate action, as a tool for transnational climate governance. While national governments and the international (intergovernmental) system continue to show, on the whole, weak and ineffectual gains in reducing the drivers of climate change, the possibility of advancing climate action through transnational governance channels shows increasing promise. Through the development of a CCRS as a transnational governance tool for heritage management and heritage tourism, we aim to highlight how heritage resources may be mobilized for responding to the challenges of anthropogenic climate change.

\section{Materials and Methods}

\subsection{Identifying a Subset of WHS for Analysis}

Recognizing the scale of the World Heritage List—composed of more than 1100 sites and with additional sites being inscribed every year-we began this study as a pilot project and needed to identify a subset of sites for analysis and development into the CCRS. We undertook a broad survey of WHS, and a subset of sites $(n=50)$ was chosen based on the following considerations: (1) most visited and iconic sites; (2) sites impacted heavily by climate change (currently or projected); (3) sites that tell important stories about anthropogenic climate change; (4) sites that have active sustainability initiatives or programs in progress; and (5) representativeness, for example in geographic distribution and site types.

Most visited and iconic sites (e.g., Angkor, the Historic Ensemble of the Potala Palace, Lhasa, and Machu Picchu) were identified through articles in media outlets such as National Geographic and through surveys conducted by TripAdvisor, a popular source of advice for travelers. These sites were included so as to increase interest in and relevance of the results of the analysis, and because as some of the most visited sites they likely generate a disproportionate share of carbon emissions from heritage tourism compared to other sites on the World Heritage List. Sites most at risk of being impacted by climate change were identified by drawing on existing studies by UNESCO World Heritage and its advisory bodies, as well as heritage experts and non-governmental organizations [18,42-45].

Attention to narrative is recognized as an increasingly vital tool for responding to the challenges of climate change $[46,47]$. Narratives provide conceptual scaffolding not only for adapting to climate 
change and mitigating its drivers, but also for mobilizing broader conversations about the moral and ethical foundations of a changing climate, and for individually processing how we face climate change in dignity, grief, sorrow, and hope. We identified sites with the narrative potential to tell stories about climate change through a process of qualitative coding [48] of the site descriptions and site documentation for the WHS [49], and associated literature, and coded for themes related to climate change. Coding allowed us to draw out those sites that offered especially holistic (integrating facets such as impacts, adaptation, mitigation, and communication) and visible cases of the nexus of heritage and climate change, as well as themes that might not be captured in the other categories under consideration. For example, sites associated with the use of fossil fuels (e.g., Cornwall and West Devon Mining Landscape, UK) help illustrate the anthropogenic contributions of carbon-based energy sources to climate change, and sites endangered by conflict influenced by climate change (e.g., Palmyra, Syria) highlight that impacts on heritage resources are not only natural or environmental (e.g., sea level rise, increased pest and mold activity) but social too.

Sites with active sustainability practices were identified through an examination of relevant documentation from UNESCO, academic literature, and through news media coverage [50,51]. Finally, sites were added to ensure that the subset was representative of the World Heritage List, with regard to factors such as type, purpose, and geographical location.

The subset of 50 sites was then organized into four subgroups: (a) sites selected for carbon footprint analysis; (b) sites with narrative potential; (c) sites with active sustainability practices; and (d) sites most impacted by climate change (see Appendix A). Some WHS were included in more than one subgroup.

\subsection{Calculating Carbon Footprints of Travel}

Ten sites were selected for calculating the carbon footprint of travel, chosen to ensure geographic and site type diversity. This study took a consumer-based approach, which allocates the emissions from tourism to the tourist, in recognition of the consumer-tourist as the main driver behind demand [12,13,52,53]. The consumption-based approach estimates the carbon footprint of at minimum three typical visits (budget, mid-range, and high-end spending) to each of these sites. For some sites, the carbon footprints for additional kinds of trips was calculated (e.g., cruise vs. land-based trips to the Galápagos Islands). For the purposes of this study, a typical trip was considered to be one in which a tourist traveled to a destination only to visit the WHS in question. Broad expenditure categories that make up the activities of tourists at these sites include local transport, accommodation, restaurant services, and recreation and leisure services, including heritage tourism activities. Excluded from the analysis was money spent on retail, such as gifts and souvenirs, and any expenditure related to travel to the point of departure in the tourist's home country. The data collected to build out an itinerary for the trip and calculate expenditures were collected from publicly-available websites used by travelers for the purpose of planning trips. These include WorldHeritageSite.org, the official UNESCO World Heritage website, including the individual webpages associated with each site (for identifying activities), Bookings.com (for collecting accommodation prices), TripAdvisor.com (for collecting price information for dining and additional activity costs, Google Flights (for identifying common flight paths), and the International Civil Aviation Organization (ICAO) Carbon Emissions Calculator (for calculating the carbon footprint of international flights).

The carbon footprints were then calculated using an input-output life cycle assessment (IO LCA) model. This model uses monetary transactions to approximate all of the material and energy inputs of a product, good, or service, and their direct and indirect emissions. A United States economy-based IO LCA model was used to calculate the carbon footprint of tourism to each site, due to the relative ease of gathering monetary expenditure data, the expansiveness of the model in terms of industry sectors, and the model's comprehensiveness in terms of incorporating upstream and indirect emissions in the carbon footprint (United States industry-based IO LCA 2002 Purchaser Price model). Expenditure data were assigned to one of the sectors in the model, and emissions for the total expenditure per 
sector were calculated and summed to get the total carbon footprint for each type of visit, excluding international air travel (Figure 1).

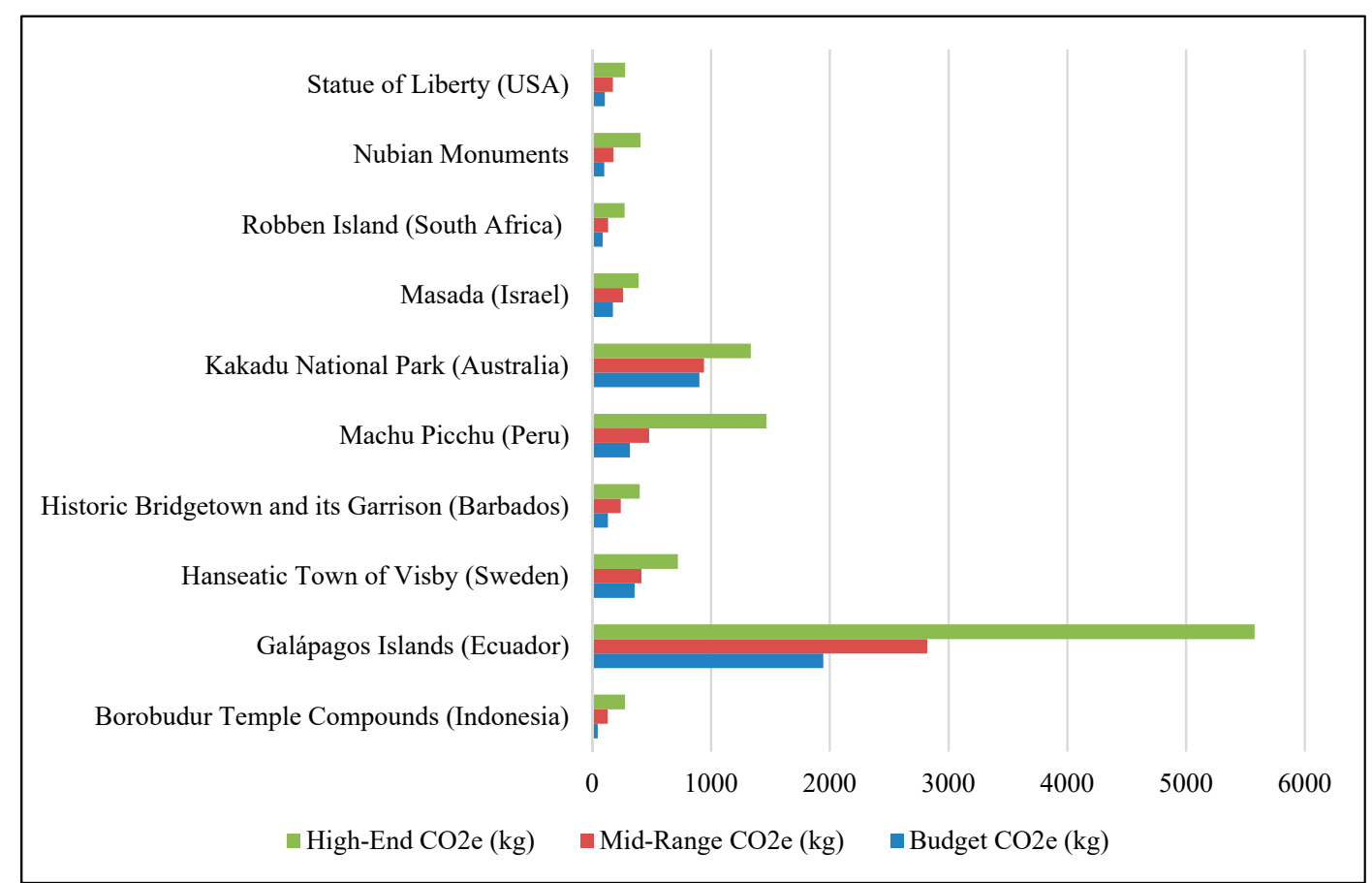

Figure 1. The average carbon dioxide equivalent (CO2e) emissions for three types of trips to selected WHS: High-End, Mid-Range, and Budget. For reference, 100 kilograms of CO2e emissions is equivalent to the carbon sequestered by growing 1.7 tree seedlings for 10 years [54]. For some sites in the CCRS we calculated multiple kinds of trips for each type (for example, multiple mid-range options using different forms of transportation), but in the above graph we have averaged these in the relevant expenditure category (High-End, Mid-Range, or Budget) to simplify the graphical representation.

To improve accuracy, this model was combined with directly calculated emissions data for international flights, using the ICAO Carbon Emissions Calculator [55]. This calculator employs industry averages for the various factors that contribute to the carbon footprint of air travel. It takes into account passenger load factors, passenger-to-cargo ratios, and fuel consumption and calculates an average fuel burn per economy class passenger. The IO LCA results were added to the ICAO international air travel results in order to calculate the total carbon footprint of each type of trip to the WHS, presented in kilograms of CO2e/trip (for an example of one site, depicting travel to Machu Picchu, see Figure 2).

It should be noted that the model used in this study is limited in its ability to accurately calculate emissions based on non-U.S. dollar expenditures, and expenditures were adjusted for inflation from 2002 to 2018. We therefore emphasize that the result is an estimated carbon footprint, used for educational purposes only. Unlike ecolabels, the recognition scheme developed here does not aim to provide rewards or certification to particular sites with lower carbon footprints, nor does it aim to set standards for carbon emissions. The recognition scheme uses carbon footprint information to provide information to the public about the potential general consequences of their travel, in an effort to increase consideration of climate effects. 


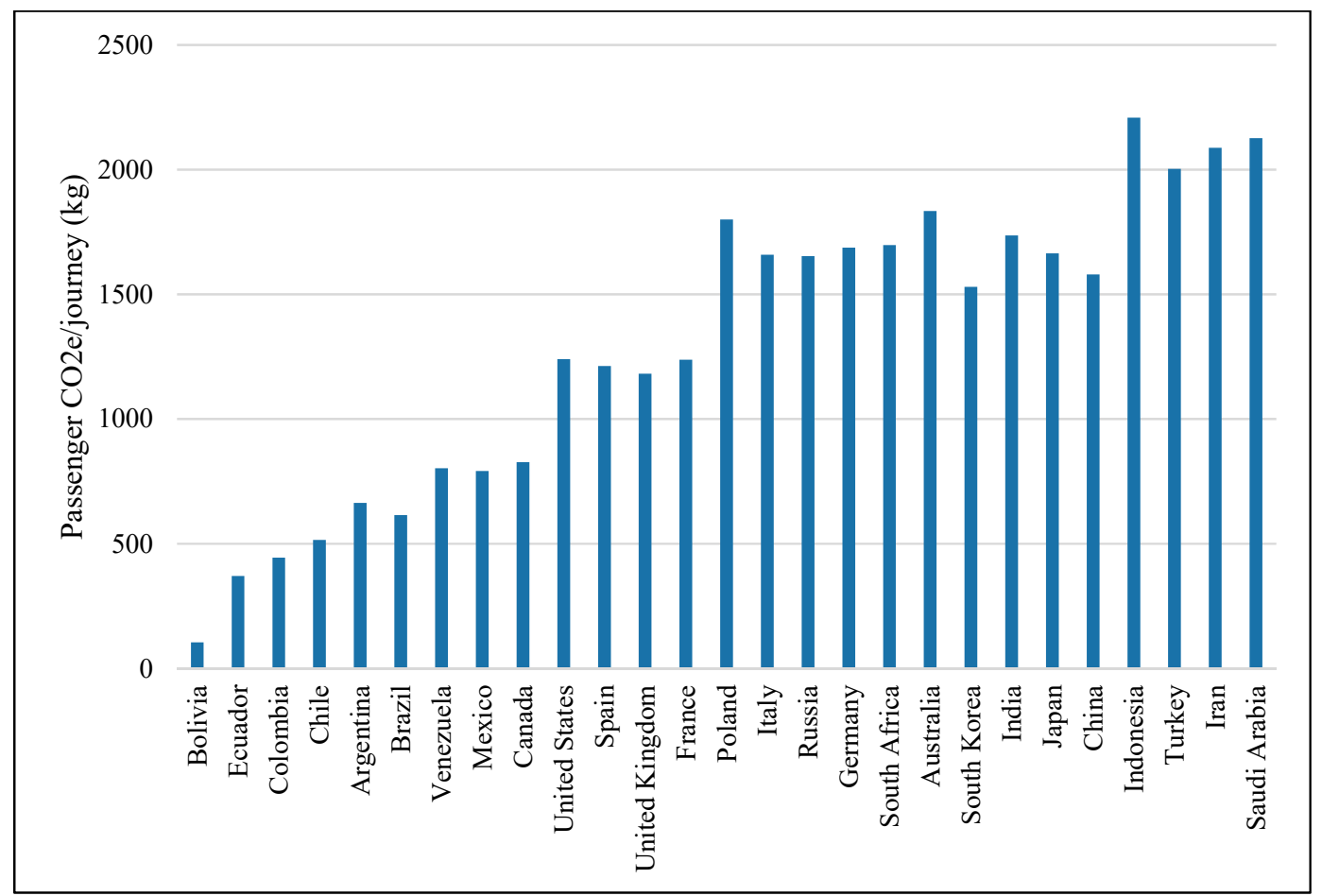

Figure 2. Carbon dioxide equivalent $(\mathrm{CO} 2 \mathrm{e})$ emissions generated in a round-trip flight from a representative airport city in each country to $\mathrm{Cusco}$, Peru, for the purpose of visiting Machu Picchu.

\subsection{Collecting Additional Climate Information}

In order to address the narrative potential presented by sites in this subgroup for climate change communication, a list of a priori themes were developed that may be applied to coding site documentation. Documentation such as advisory body evaluations, media articles related to the site, site management plans, UNESCO mission reports, periodic reporting by the State Party, and other relevant reports were collected from the UNESCO website and other web sources. These were analyzed using NVivo 12 through a directed approach to content analysis [56]. As analysis proceeded, additional themes arose, and some themes were combined to clarify patterns. The final list of themes addressed topics such as conflict, education, environment, climate change impacts, biodiversity, industrial heritage, public engagement, sustainable development, and transnationalism. Patterns amongst the data were then drawn out and used as a framework for a brief narrative about how best to draw a visitor into a story about climate change at the site.

Identification of sustainability practices took place through reviews of site documentation, work conducted by UNESCO and other researchers, and news media. Sustainability measures considered include, for example, aggressive action towards increased use of renewable energy, acknowledgment of the importance of energy audits and reducing energy use, and embracing renewable energy at the beginning of electrification projects.

Climate change impacts were identified through reviews of site documentation, UNESCO reports, news media, and academic work. Vulnerabilities to climate change and previously-recorded impacts of climate change on sites were documented. These focused on the physical, direct impacts of climate change on the site. Damage caused by conflict related to climate change was not included in this section (but was considered for the narrative potential of sites).

\section{Results}

The data on carbon footprints, climate narratives, sustainability practices, and climate change impacts were imported into ArcGIS Online, a free, open-source, cloud-based mapping tool. The ArcGIS StoryMaps platform was then used to combine the text, images of sites, and interactive maps to 
create a publicly-accessible platform to present the results of the analysis, developed as a Climate Communication Recognition Scheme titled Climate Footprints of Heritage Tourism [41]. The StoryMap interface allows for the creation of interactive web-based platforms built around the presentation of spatial information through maps. By linking narrative text with photographs and maps of spatial relationships, StoryMaps are a rich, visually compelling way to present information that engages the reader and facilitates dissemination [57,58]. ArcGIS StoryMaps are increasingly being used across fields to communicate information, including in education, public health, museum studies, and geology [59-62].

The StoryMap developed in this project presents the data collected for each of the subgroups in two overarching themes: Understanding Your Impact and Telling the Story:

- Understanding Your Impact provides an opportunity to learn about the effects of travel to WHS through the carbon footprint analysis. This section includes a description of what carbon footprint analysis is and the methodology for this part of the project. It then provides the results of the carbon footprint analysis in narrative form for each of ten WHS (Figure 3). Each site description concludes with an interactive map that shows the carbon cost of international flights to the WHS from 1 of at least 20 countries, which represent the 20 countries with the greatest carbon emissions in 2015 [63] and the countries which send the most tourists to the WHS country.

- Telling the Story provides a hub of information about the ways climate change and World Heritage are related, through climate narratives, sustainability actions, and climate change impacts (Figure 4). This section of the platform highlights the WHS for each subgroup on a world map, including the site's spatial location, photographs, narrative text, and links to more information.

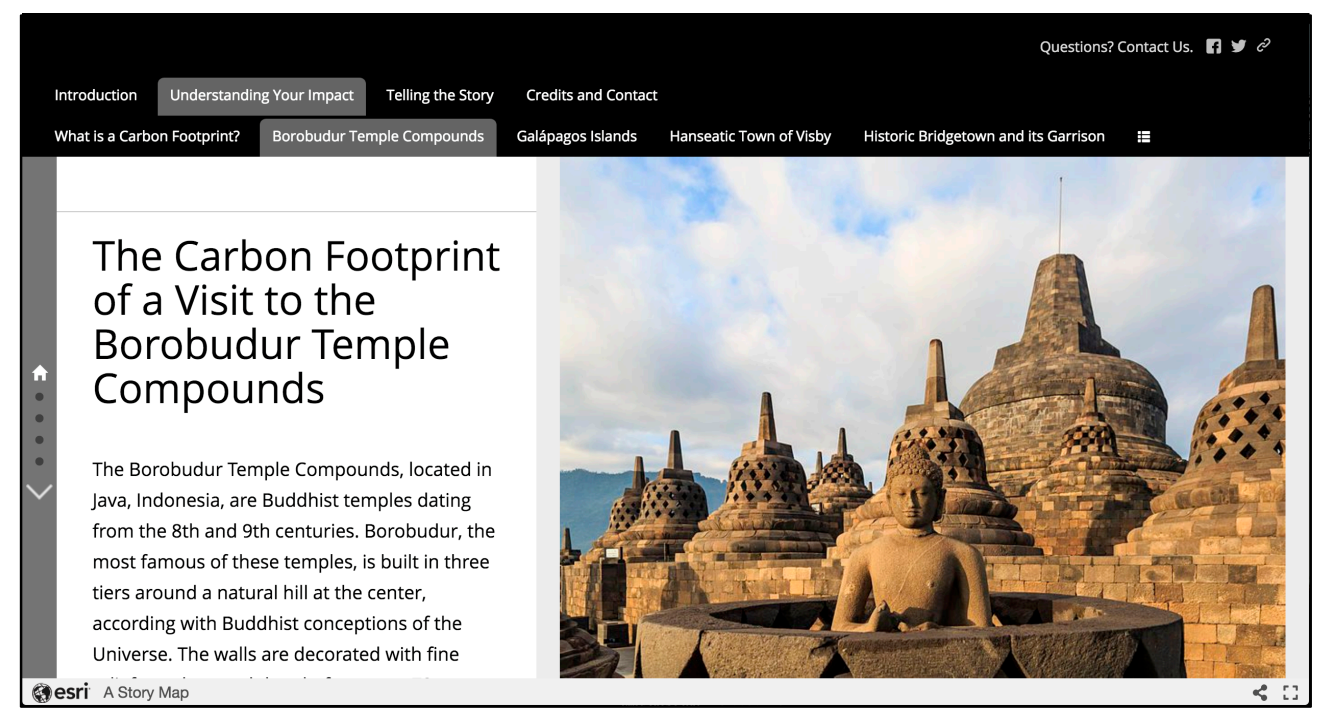

Figure 3. Webpage screenshot of Understanding Your Impact theme, with example of the site of the Borobudur Temple Compounds, in the StoryMap Climate Footprints of Heritage Tourism [41]. 


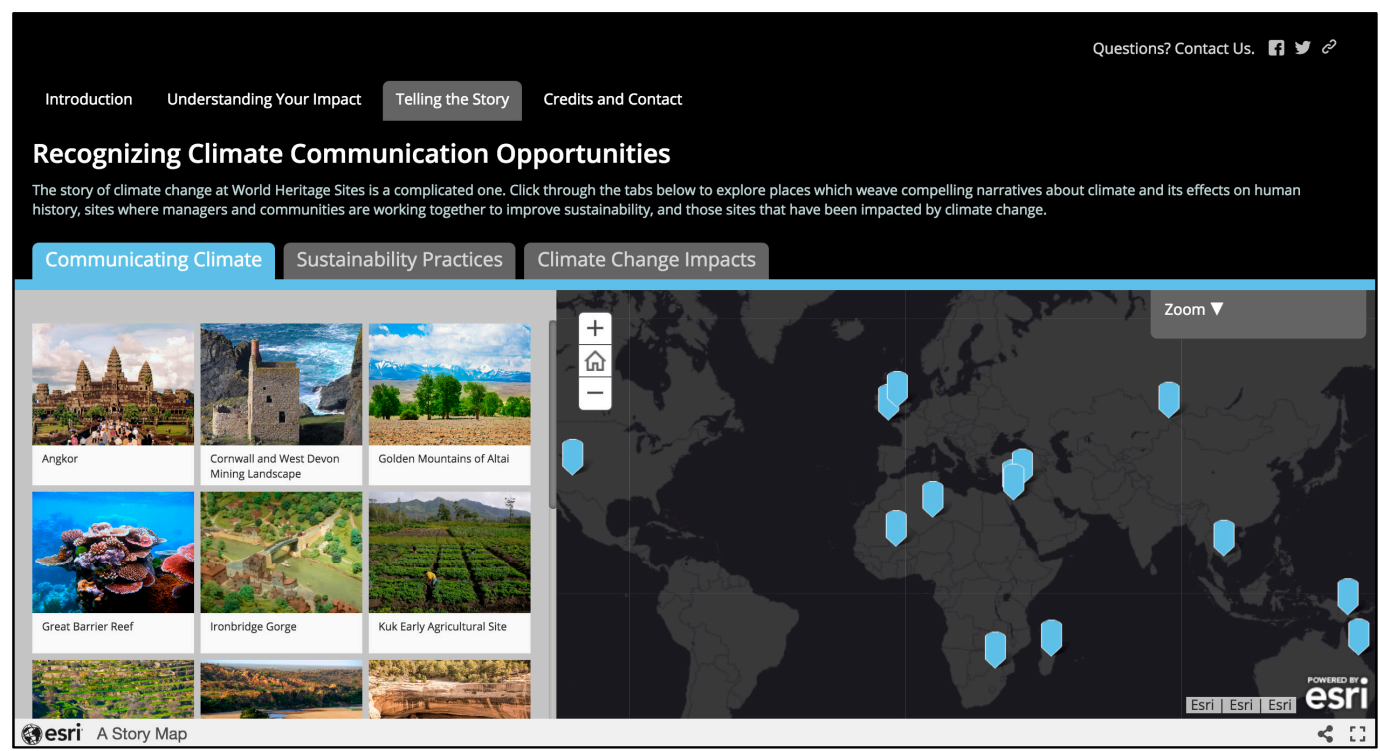

Figure 4. Webpage screenshot of Telling the Story theme in the StoryMap Climate Footprints of Heritage Tourism [41].

\section{Discussion: Climate Communication Recognition Schemes as a Transnational Governance Tool}

This study represents a pilot approach for developing a public-facing instrument that uses heritage sites to communicate various facets of climate change, including information relevant for mitigation and adaptation responses. Specifically, we developed the instrument as a CCRS to provide a tool for transnational governance. CCRS is an elaboration on the concept of ecolabels, but with two primary distinctions: a CCRS is specifically oriented towards climate concerns and captures a more holistic portrait, for example of the entanglements between heritage resources and climate change, than the strictly quantitative measures typically employed and available in ecolabels. We consider that the development of ecolabels and CCRS will strengthen the knowledge base for sustainable site management and consumer decision-making in the face of global climate change; most importantly, such instruments represent mechanisms for transnational governance of climate issues, in the context of the deficits and dysfunction in the international governance of climate change responses.

Increasingly issues or policy problems-like global climate change-that impact heritage resources and their management extend beyond state jurisdictions. Furthermore, they are poorly addressed or captured by the traditional international system of state-to-state treaties and treaty-based intergovernmental organizations, for example by UNESCO World Heritage and its system of conventions, recommendations, and associated advising bodies. International organizations like UNESCO are subject to the grindingly slow machinery of national and international governance, which have proven inadequate to address the rising environmental and social challenges of climate change. Additionally, some of the deficits in the ability of UNESCO heritage frameworks to respond in a meaningful way to climate change are baked into UNESCO's conventions. International agreements like the UNESCO conventions related to heritage (e.g., the 1972 Convention Concerning the Protection of the World Cultural and Natural Heritage and the 2003 Convention for the Safeguarding of the Intangible Cultural Heritage) make no explicit reference to climate change, though the World Heritage Convention does address threats to heritage sites presented by extreme weather [64]. Indeed, though scholars and climate activists have explored the extent to which the World Heritage Convention might be used to compel States Parties to take action on climate change $[65,66]$, others reiterate that these conventions assert the rights of states to protect their own heritage sites, and do not enforce obligations to mitigate climate change [67]. Despite the shortcomings of UNESCO World Heritage as an international governmental body, we do find value in the branding function-as a brand signifying 
global conservation - that UNESCO World Heritage has come to take on, especially in the shift towards development models of heritage management. This branding function may be usefully developed as a transnational governance tool: as an ecolabel or, in this case, the development and refinement of an ecolabel as a CCRS.

Scholars and actors in climate governance are turning to transnational governance as one of the most promising arenas for climate action [68-70]. Given the limitations of the international system for cross-border governance and interstate cooperation, developing transnational governance tools (like ecolabels) offers the opportunity for institutional innovations that better fit heritage management practices to the challenges of global climate change. The search for institutional innovations in climate governance is the rationale for this study to develop a CCRS for WHS. More broadly, heritage resources and heritage practices increasingly cross national borders, underscoring the need for the further development of heritage management paradigms within transnational frameworks [39,71].

It is important to understand that, across various sectors and contexts, transnational governance has assumed similar functions as the state and the international system, such as rule-making, implementation, monitoring, enforcement, and service provision. However, transnational governance is different from state governments and international system on account of having shed the administrative and institutional trappings of these governmental bodies. This move from the state/international to transnational is perhaps best understood as a shift from "governments" to "governance." This shift has been ongoing for some time now, as structural adjustments to government under neoliberal reforms have encouraged the decentralization of state bureaucracies and withdrawal of the state from social provisioning.

In general, transnational governance is characterized by several key trends: (1) merging of domestic and international politics; (2) increasing involvement of non-state actors (e.g., individuals, firms, corporations, and NGOs) in global politics, in providing technical expertise, monitoring, lobbying, or enforcement; (3) private governance, e.g., the involvement of private foundations in global standards, such as the Gates Foundation in global health; and (4) new methods for eliciting compliance with transborder standards, such as 'naming and shaming,' capacity building, persuasion, transparency, and dissemination of best practices [72] (pp. 6-12). Overall, governance mechanisms for organizing action and eliciting compliance-e.g., through the private sphere, non-governmental organizations (NGOs), and corporate social responsibility (CSR)—are being sought beyond the international system.

Ecolabels fit squarely within the above trends, as they are typically developed by non-state actors, represent a form of private governance, and provide a tool for eliciting compliance. Ecolabeling uses a certification process to assign labels to consumer goods, e.g., organic and fair trade certification of food, for communicating the sustainability of a product [73-75]. Ecolabels extend to tourism; for example $30 \%$ (128 of 430) of the ecolabels listed in the 2014 Ecolabel Index apply to the tourism industry [74]. In the context of the tourism industry, these schemes often carry a strong quantifiable and ecological focus. However, efforts to incorporate cultural, social, and economic aspects of a tourist destination into these schemes are underway and are often reflected in a more holistic approach to certification processes known as an "environmental product information scheme" (EPIS) that aim to provide more holistic ecological information on products and services [75-78]. The emergence of voluntary transnational governance tools for encouraging and recognizing environmental sustainability has resulted in a variety of instruments that can collectively be called EPIS. These schemes include mechanisms such as ecolabels, stewardship certificates, green trademarks, rankings and ratings, codes of conduct, and standards for reports and declarations, among others [79,80]. Ecolabels and EPIS are employed to communicate information to consumers, such as quality and sustainability, and reward and promote goods and services that are environmentally superior in some respect [75]. They provide consumers with the opportunity to "vote with their wallet" in a manner of environmental policymaking that extends beyond national governments and borders.

The current study is situated within this literature and, as described above, aims to develop an environmental product information scheme for communicating climate change at WHS, which we 
have called a "climate communication recognition scheme" (CCRS). This elaboration from an ecolabel to a more holistic capturing of the various facets of climate change knowledge and responses immanent in heritage sites is reflected in our choices in designing the CCRS. In addition to the quantitative measures that typically characterize ecolabels, given in this case by carbon footprint analysis, we have also chosen to portray other facets of climate change at heritage sites, such as their narrative potential for communicating the histories of anthropogenic climate change, the sustainability practices being undertaken at heritage sites, and the impacts of climate change to heritage resources. We consider this approach a more accurate capturing of the climate communication potential of heritage sites, not only pursuing carbon management tools like carbon footprint analysis, but also triangulated with social justice and sustainability issues attendant with heritage sites and global climate change (for example, exacerbating existing social and economic inequalities, the fundamental and paradoxical inequalities of climate change between who contributes and who suffers, and the impacts of climate change for increasing migration, displacement, conflict, and food insecurity). WHS are iconic institutions representing the cultural riches and creative solutions that societies around the world have produced in relationship to their environment, so it is important that an ecolabel for WHS is situated within a holistic context of social, economic, and environmental sustainability and attentive to the social justice dimensions of global climate change.

One of the limitations of this study is the time-intensive nature of collecting information for each of the WHS included in the StoryMap. Given the sheer number of sites on the World Heritage List, expanding the approach taken here to the entire list would require significant time investment and is probably unrealistic. Plus, taking into account that new sites are inscribed to the World Heritage List each year, we suggest that any CCRS for WHS should be considered a "living" and provisional labeling tool rather than an exhaustive one. Therefore, future development of the CCRS beyond our pilot-study will need to set evaluative rubrics for which WHS should be prioritized over others for inclusion in the CCRS. The calculation of carbon footprints of travel to the sites is also particularly time-intensive, as it requires collecting considerable amounts of data from various online sources. A further limitation of the carbon footprint calculations, in addition to those discussed in the methods section above, is that these footprints were calculated under the assumption that the tourist was traveling only to the site in question. Generally, heritage tourism is part of a tourism circuit, in which visitors to a country travel to several locations on one trip [81].

Following this pilot-study, we plan to continue developing and refining the CCRS for eventual dissemination amongst heritage managers and specialists as well as the general public. In addition to increasing the number of sites represented in the CCRS, we also intend to continue building out the narrative descriptions for each site, especially to underscore the holistic nexus of climate impacts, adaptive capacity, carbon management and other mitigatory actions, and climate communication opportunities that exist, or have the potential to exist, at every site. A holistic approach to climate change in site management, heritage management, and public engagement with heritage sites will offer better opportunities and strengthen resilience for responding to the challenges of climate change. Furthermore, our work with the CCRS mirrors broader developments in formalizing the inclusion of climate considerations in heritage management, and though these trends are still primarily focused on impacts and adaptation, such analyses and instruments as provided here may be of interest in strengthening and institutionalizing climate change responses within heritage site management and heritage management more broadly.

Overall, we offer this study as an example of the development of transnational governance tools in heritage management for addressing climate change, and we recommend further research and initiatives in this direction. As we develop in this study, an ecolabeling scheme for WHS that communicates the holistic facets of climate change could influence consumer/tourist choices and site management for a well-known "brand" of tourism sites that trades on global awareness and global conservation. We urge further development of transnational tools for heritage management in order to meet the climate crisis. The ineffectiveness of climate action within the international system behooves 
stakeholders of heritage resources to pursue sustainable development and sustainable tourism via low-carbon economic growth and to innovate and incorporate transnational tools for responding to climate change, which will serve to "fill in the gaps" or provide supportive scaffolding to international and national heritage policies and practices.

Author Contributions: All authors helped in methodology, formal analysis, investigation, data curation, and developing the manuscript. Conceptualization, funding acquisition, and supervision, K.L.S. All authors have read and agreed to the published version of the manuscript.

Funding: This research was funded by the University of Maryland ADVANCE Program for Inclusive Excellence and the University of Maryland Department of Anthropology.

Acknowledgments: We wish to thank Klaus Hubacek for his advice during the conceptualization of this project, and Paul Shackel and Barnet Pavão-Zuckerman for their feedback on the development of the StoryMap. This paper benefitted from the insightful recommendations of five anonymous reviewers, and we thank them for their time and attention. We are also grateful for website support from the University of Maryland Department of Anthropology for the website http://www.heritageofclimate.com.

Conflicts of Interest: The authors declare no conflict of interest.

\section{Appendix A}

Subgroups of WHS chosen for climate communication recognition scheme Climate Footprints of Heritage Tourism (some sites are included in more than one subgroup):

\section{(a) Carbon Footprint Analysis}

1. Borobudur Temple Compounds

2. Galapágos Islands

3. Hanseatic Town of Visby

4. Historic Bridgetown and Garrison

5. Historic Sanctuary of Machu Picchu

6. Kakadu National Park

7. Masada

8. Nubian Monuments from Abu Simbel to Philae

9. Robben Island

10. Statue of Liberty

\section{(b) Sites with Narrative Potential}

11. Angkor

12. Cornwall and West Devon Mining Landscape

13. Golden Mountains of Altai

14. Great Barrier Reef

15. Ironbridge Gorge

16. Kuk Early Agricultural Site

17. Land of Olives and Vines

18. Mapungubwe Cultural Landscape

19. Mesa Verde National Park

20. Palmyra

21. Petra

22. Royal Hill of Ambohimanga

23. Tassili n'Ajjer

24. Timbuktu 


\section{(c) Sites Pursuing Sustainability Practices}

25. Costiera Amalfitana

26. Ferrara, City of the Renaissance, and its Po Delta

27. Galapágos Islands

28. Golden Mountains of Altai

29. Great Barrier Reef

30. Hanseatic Town of Visby

31. Historic Centre of Oaxaca and Archaeological Site of Monte Albán

32. Loire Valley between Sully-sur-Loire and Chalonnes

33. Old and New Towns of Edinburgh

34. Petra

35. Rice Terraces of the Philippine Cordilleras

36. Robben Island

37. Routes of Santiago de Compostela (Camino de Santiago)

38. Taj Mahal

\section{(d) Sites Most Impacted by Climate Change (Current and Projected)}

39. Agave Landscape and Ancient Industrial Facilities of Tequila

40. Ancient Ksour of Ouadane, Chinguetti, Tichitt and Oualata

41. Borobudur Temple Compounds

42. Cilento and Vallo di Diano National Park with the Archaeological Sites of Paestum and Velia, and the Certosa di Padula

43. Coffee Cultural Landscape

44. Cornwall and West Devon Mining Landscape

45. Costiera Amalfitana

46. Ferrara, City of the Renaissance, and its Po Delta

47. Galapágos Islands

48. Golden Mountains of Altai

49. Great Barrier Reef

50. Historic Bridgetown and Garrison

51. Historic Sanctuary of Machu Picchu

52. Historical Complex of Split with the Palace of Diocletian

53. Hoi, An Ancient Town

54. Ibiza, Biodiversity and Culture

55. Kakadu National Park

56. Landscape of the Pico Island Vineyard Culture

57. Lavaux, Vineyard Terraces

58. Medina of Essaouria (Mogador)

59. Mesa Verde National Park

60. Ouadi Qadisha (the Holy Valley) and the Forest of the Cedars of God

61. Port, Fortresses and Group of Monuments, Cartagena

62. Rice Terraces of the Philippine Cordilleras

63. Robben Island

64. Ruins of Kilwa Kisiwani and Ruins of Songo Mnara

65. Saloum Delta

66. SGang Gwaay

67. Statue of Liberty 
68. Timbuktu

69. Venice and its Lagoon

70. Viñales Valley

\section{References}

1. Gössling, S. Carbon Management in Tourism: Mitigating the Impacts on Climate Change; Routledge: New York, NY, USA, 2010.

2. Hall, C.M.; Scott, D.; Gössling, S. The primacy of climate change for sustainable international tourism. Sustain. Dev. 2013, 21, 112-121. [CrossRef]

3. Scott, D.; Hall, C.M.; Gössling, S. Tourism and Climate Change: Impacts, Adaptation and Mitigation; Routledge: New York, NY, USA, 2012.

4. Scott, D.; Gössling, S.; Hall, C.M. International tourism and climate change. Wiley Interdiscip. Rev. Clim. Chang. 2012, 3, 213-232. [CrossRef]

5. Hall, C.M. Heritage, heritage tourism and climate change. J. Herit. Tour. 2016, 11, 1-9. [CrossRef]

6. UNWTO (United Nations World Tourism Organization), UNEP (United Nations Environment Programme), and WMO (World Meteorological Organization). Climate Change and Tourism: Responding to Global Challenges; UNWTO/UNEP/WMO: Madrid, Spain, 2008.

7. WEF (World Economic Forum). Towards a Low Carbon Travel and Tourism Sector; World Economic Forum: Davos, Switzerland, 2009.

8. Lenzen, M.; Sun, Y.-Y.; Faturay, F.; Ting, Y.-P.; Geschke, A.; Malik, A. The carbon footprint of global tourism. Nat. Clim. Change 2018, 8, 522-528. [CrossRef]

9. International Air Transport Association (IATA). IATA Forecast Predicts 8.2 Billion Air Travelers in 2037 [Summary of IATA 20-year Passenger Forecast]. 2018. Available online: http://www.iata.org/pressroom/pr/ Pages/2018-10-24-02.aspx (accessed on 31 October 2019).

10. Gössling, S.; Hall, C.M. Tourism and Global Ecological Change: Ecological, Social, Economic and Political Interrelationships; Routledge: New York, NY, USA, 2006.

11. Becken, S.; Hay, J. Climate Change and Tourism: From Policy to Practice; Routledge: New York, NY, USA, 2012.

12. Kuo, N.-W.; Lin, C.-Y.; Chen, P.-H.; Chen, Y.-W. An inventory of the energy use and carbon dioxide emissions from island tourism based on a life cycle assessment approach. Environ. Prog. Sustain. Energy 2012, 31, 3-465. [CrossRef]

13. Filimonau, V.; Dickinson, J.; Robb ins, D.; Reddy, M.V. The role of 'indirect' greenhouse gas emissions in tourism: Assessing the hidden carbon impacts from a holiday package tour. Trans. Res. Part A Policy Pract. 2013, 54, 78-91. [CrossRef]

14. Hall, C.M.; Baird, T.; James, M.; Ram, Y. Climate change and cultural heritage: Conservation and heritage tourism in the Anthropocene. J. Herit. Tour. 2016, 11, 1-24. [CrossRef]

15. Hansen, J. Storms of My Grandchildren: The Truth About the Coming Climate Catastrophe and Our Last Chance to Save Humanity; Bloomsbury: New York, NY, USA, 2009.

16. Beniston, M. Sustainability of the landscape of a UNESCO World Heritage Site in the Lake Geneva Region (Switzerland) in a greenhouse climate. Int. J. Climatol. 2007, 28, 1519-1524. [CrossRef]

17. Burns, W.C.G. Belt and suspenders? The World Heritage Convention's role in confronting climate change. Rev. Eur. Commun. Int. Environ. Law 2009, 18, 148-163. [CrossRef]

18. Burt, S.; Boom, K.; Lawrence, J.; Leonard, S.; Rosenthal, E.; Wagner, J.M. The Role of Black Carbon in Endangering World Herit. Sites Threatened by Glacial Melt and Sea Level Rise; Earthjustice and Australian Climate Justice Program: Oakland, CA, USA; Ultimo, Australia, 2009.

19. Dawson, J.; Johnston, M.J.; Stewart, E.J.; Lemieux, C.J.; Lemelin, R.H.; Maher, P.T.; Grimwood, B.S.R. Ethical Considerations of Last Chance Tourism. J. Ecotour. 2011, 10, 250-265. [CrossRef]

20. Frew, E.A. Advertising World Heritage Sites: Tour Operators and Last Chance Destinations. In Last Chance Tourism: Adapting Tour. Opportunities in a Changing World; Lemelin, R.H., Dawson, J., Stewart, E.J., Eds.; Routledge: New York, NY, USA, 2012; pp. 117-132.

21. Lemelin, H.; Dawson, J.; Stewart, E.J.; Maher, P.; Lueck, M. Last-chance tourism: The boom, doom, and gloom of visiting vanishing destinations. Curr. Issues Tour. 2010, 13, 477-493. [CrossRef] 
22. Lemelin, H.R.; Dawson, J.; Stewart, E.J. Last Chance Tour.: Adapting Tour. Opportunities in a Changing World; Routledge: Abingdon, UK, 2012.

23. Eijgelaar, E.; Thaper, C.; Peeters, P. Antarctic cruise tourism: The paradoxes of ambassadorship, 'last chance tourism,' and greenhouse gas emissions. J. Sustain. Tour. 2010, 18, 337-354. [CrossRef]

24. Dawson, J.; Stewart, E.J.; Lemelin, H.; Scott, D. The carbon cost of polar bear viewing tourism in Churchill, Canada. J. Sustain. Tour. 2010, 18, 319-336. [CrossRef]

25. Buckley, R. The effects of World Heritage listing on tourism to Australian national parks. J. Sustain. Tour. 2004, 12, 70-84. [CrossRef]

26. PricewaterhouseCoopers. The Costs and Benefits of UK World Heritage Site Status; UK Department for Culture, Media and Sport: London, UK, 2007.

27. Rebanks Consulting, and Trends Business Research. World Heritage Status: Is There Opportunity for Economic Gain. In Research and Analysis of the Socio-Economic Impact Potential of UNESCO World Heritage Site Status; Lake District World Heritage Project: Kendal, UK, 2009.

28. Su, Y.-W.; Lin, H.-L. Analysis of international tourist arrivals worldwide: The role of World Heritage Sites. Tour. Manag. 2014, 40, 46-58. [CrossRef]

29. Yang, C.-H.; Lin, H.-L.; Han, C.-C. Analysis of international tourist arrivals in China: The role of World Heritage Sites. Tour. Manag. 2010, 31, 827-837. [CrossRef]

30. Adie, B.A. Franchising our heritage: The UNESCO World Heritage brand. Tour. Manag. Perspect. 2017, 24, 48-53. [CrossRef]

31. King, L.M.; Halpenny, E.A. Communicating the World Heritage brand: Visitor awareness of UNESCO's World Heritage symbol and the implications for sites, stakeholders and sustainable management. J. Sustain. Tour. 2014, 22, 768-786. [CrossRef]

32. Ryan, J.; Silvanto, S. A study of the key strategic drivers of the use of the World Heritage Site designation as a destination brand. J. Travel Tour. Mark. 2014, 31, 327-343. [CrossRef]

33. Wuepper, D.; Patry, M. The World Heritage List: Which sites promote the brand? A big data spatial econometrics approach. J. Cult. Econ. 2017, 41, 1-21. [CrossRef]

34. Drost, A. Developing sustainable tourism for World Heritage Sites. Annal. Tour. Res. 1996, 23, 479-484. [CrossRef]

35. Landorf, C. Managing for sustainable tourism: A review of six cultural World Heritage Sites. J. Sustain. Tour. 2009, 17, 53-70. [CrossRef]

36. Schmutz, V.; Elliott, M.A. Tourism and sustainability in the evaluation of World Heritage Sites, 1980-2010. Sustainability 2016, 8, 261-275. [CrossRef]

37. Nzama, A.T. The nexus between sustainable livelihoods and ecological management of the World Heritage Sites: Lessons from iSimangaliso World Heritage Park, South Africa. Inkanyiso J. Hum. Soc. Sci. 2009, 1, 34-42. [CrossRef]

38. Li, M.; Wu, B.; Cai, L. Tourism development of World Heritage Sites in China: A geographic perspective. Tour. Manag. 2008, 29, 308-319. [CrossRef]

39. Lafrenz Samuels, K. Transnational turns for archaeological heritage: From conservation to development, governments to governance. J. Field Archaeol. 2016, 41, 355-367. [CrossRef]

40. Lafrenz Samuels, K.; Lilley, I. Transnationalism and Heritage Development. In Global Heritage: A Reader; Meskell, L., Ed.; Blackwell: Malden, MA, USA, 2015; pp. 217-239.

41. Climate Footprints of Heritage Tourism. Available online: http://heritageofclimate.com (accessed on 4 March 2020).

42. Markham, A.; Osipova, E.; Lafrenz Samuels, K.; Caldas, A. World Heritage and Tour. in a Changing Climate; United Nations Environment Programme (UNEP) \& United Nations Educational, Scientific and Cultural Organization (UNESCO): Nairobi, Kenya; Paris, France, 2016.

43. Marzeion, B.; Levermann, A. Loss of cultural World Heritage and currently inhabited places to sea-level rise. Environ. Res. Lett. 2014, 9, 3-7. [CrossRef]

44. United Nations Educational, Scientific and Cultural Organization (UNESCO). Case Studies on Climate Change and World Heritage; UNESCO: Paris, France, 2007.

45. United Nations Educational, Scientific and Cultural Organization (UNESCO). Policy Document on the Impacts of Climate Change on World Heritage Properties; UNESCO: Paris, France, 2008. 
46. Fløttum, K.; Gjerstad, Ø. Narratives in climate change discourse. Wiley Interdiscip. Rev. Clim. Change 2017, 8, e429. [CrossRef]

47. Coulter, L.; Serrao-Neumann, S.; Coiacetto, E. Climate Change adaptation narratives: Linking climate knowledge and future thinking. Futures 2019, 111, 57-70. [CrossRef]

48. Saldaña, J. The Coding Manual for Qualitative Researchers; SAGE Publications: London, UK, 2009.

49. Available online: http://whc.unesco.org/en/list/ (accessed on 4 March 2020).

50. Benchikh, O.; Cipriano, M. Good Practices: Success Stories on Sustainable and Renewable Energies in UNESCO Sites; UNESCO: Paris, France, 2013.

51. Booysen, J. Robben Island Is Going Solar. IOL Business Report. 18 May 2018. Available online: http://www. iol.co.za/business-report/energy/robben-island-is-going-solar-15029020 (accessed on 4 November 2019).

52. El Hanandeh, A. Quantifying the carbon footprint of religious tourism: The case of Hajj. J. Clean. Prod. 2013, 52, 53-60. [CrossRef]

53. Sharp, H.; Grundius, J.; Heinonen, J. Carbon footprint of inbound tourism to Iceland: A consumption-based life-cycle assessment including direct and indirect emissions. Sustainability 2016, 8, 11. [CrossRef]

54. United States Environmental Protection Agency Greenhouse Gas Equivalencies Calculator. Available online: http://www.epa.gov/energy/greenhouse-gas-equivalencies-calculator (accessed on 4 March 2020).

55. International Civil Aviation Organization (ICAO) Carbon Emissions Calculator. Available online: http: //www.icao.int/environmental-protection/Carbonoffset/Pages/default.aspx (accessed on 4 March 2020).

56. Hsieh, H.-F.; Shannon, S.E. Three approaches to qualitative content analysis. Qual. Health Res. 2005, 15, 1277-1288. [CrossRef] [PubMed]

57. Molden, O.C. Short take: Story-mapping experiences. Field Methods 2019, 1-9. [CrossRef]

58. West, H.; Horswell, M. GIS has changed! Exploring the potential of ArcGIS online. Teach. Geogr. 2018, 43, 22-24.

59. Walshe, N. Using ArcGIS online story maps. Teach. Geogr. 2016, 41, 115-117.

60. Rauch, S. Mapping PPS: A case study of story map journals for interactive health reporting. Online J. Public Health Inf. 2019, 11, e313. [CrossRef]

61. Hunt, R.A. Accessibility of Museum Collections through ArcGIS Story Maps at Lake Champlain Maritime Museum. Master's Thesis, State University of New York at Binghamton, New York, NY, USA, 2019.

62. Antoniou, V.; Ragia, L.; Nomikou, P.; Bardouli, P.; Lampridou, D.; Ioannou, T.; Kalisperakis, I.; Stentoumis, C. Creating a story map Using Geographic Information Systems to explore geomorphology and history of Methana Peninsula. ISPRS Int. J. Geo-Inf. 2018, 7, 12. [CrossRef]

63. Union of Concerned Scientists. Each Country's Share of CO2 Emissions (10 October 2018). Available online: http://www.ucsusa.org/global-warming/science-and-impacts/science/each-countrys-share-of-co2. html (accessed on 4 November 2019).

64. Carducci, G. What Consideration Is Given to Climate and to Climate Change in the UNESCO Cultural Heritage and Property Conventions? In Climate Change as a Threat to Peace: Impacts on Cultural Heritage and Cultural Diversity; von Schorlemer, S., Maus, S., Eds.; PL Academic Research: Frankfurt am Main, Germany, 2014; pp. 129-139. Available online: http://www.jstor.org/stable/j.ctv2t4cvp (accessed on 4 March 2020).

65. Chechi, A. The Cultural Dimension of Climate Change: Some Remarks on the Interface Between Cultural Heritage and Climate Change Law. In Climate Change as a Threat to Peace: Impacts on Cultural Heritage and Cultural Diversity; von Schorlemer, S., Maus, S., Eds.; PL Academic Research: Frankfurt am Main, Germany, 2014; pp. 161-197. Available online: http://www.jstor.org/stable/j.ctv2t4cvp (accessed on 4 March 2020).

66. Quirico, O. Key Issues in the Relationship Between the World Heritage Convention and Climate Change Regulation. In Cultural Heritage, Cultural Rights, Cultural Diversity: New Developments in International Law; Borelli, S., Lenzerini, F., Eds.; Studies in Intercultural Human Rights 4. Martinus Nijhoff Publishers: Leiden, The Netherlands, 2012; pp. 291-412.

67. Lenzerini, F. Protecting the Tangible, Safeguarding the Intangible: A Same Conventional Model for Different Needs. In Climate Change as a Threat to Peace: Impacts on Cultural Heritage and Cultural Diversity; von Schorlemer, S., Maus, S., Eds.; PL Academic Research: Frankfurt am Main, Germany, 2014; pp. 141-160. Available online: https://www.jstor.org/stable/j.ctv2t4cvp (accessed on 4 March 2020).

68. Bulkeley, H.; Andonova, L.B.; Betsill, M.M.; Compagnon, D.; Hale, T.; Hoffmann, M.J.; Newell, P.; Paterson, M.; VanDeveer, S.D.; Roger, C. Transnational Climate Change Governance; Cambridge University Press: Cambridge, UK, 2014. 
69. Andonova, L.B.; Hale, T.N.; Roger, C.B. The Comparative Politics of Transnational Climate Governance; Routledge: New York, NY, USA, 2019.

70. Hickmann, T. Rethinking Authority in Global Climate Governance: How Transnational Climate Initiatives Relate to the International Climate Regime; Routledge: New York, NY, USA, 2015.

71. Lafrenz Samuels, K. Mobilizing Heritage: Anthropological Practice and Transnational Prospects; University Press of Florida: Gainesville, FL, USA, 2018.

72. Hale, T.; Held, D. Handbook of Transnational Governance: Institutions and Innovations; Polity Press: Cambridge, UK, 2011.

73. Bolwig, S.; Gibbon, P. Emerging Product Carbon Footprint Standards and Schemes and their Possible Trade Impacts; Risø National Laboratory for Sustainable Energy, Technical University of Denmark: Roskilde, Denmark, 2009.

74. Gössling, S.; Buckley, R. Carbon labels in tourism: Persuasive communication? J. Clean. Prod. 2016, 111, 358-369. [CrossRef]

75. Rubik, F.; Frankl, P. The Future of Eco-Labelling: Making Environmental Product Information Systems Effective; Greenleaf Publishing: Sheffield, UK, 2005.

76. Das, M.; Chatterjee, B. Ecotourism: A panacea or a predicament? Tour. Manag. Perspect. 2015, 14, 3-16. [CrossRef]

77. Melissen, F.; Koens, K.; Brinkman, M.; Smit, B. Sustainable development in the accommodation sector: A social dilemma perspective. Tour. Manag. Perspect. 2016, 20, 141-150. [CrossRef]

78. Tepelus, C.M.; Córdoba, R.C. Recognition schemes in tourism-From 'eco' to 'sustainability'? J. Clean. Prod. 2005, 13, 135-140. [CrossRef]

79. Scheer, D.; Rubik, F. Environmental Product Information Schemes: An overview. In The Future of Eco-Labelling: Making Environmental Product Information Systems Effective; Rubik, F., Frankl, P., Eds.; Greenleaf Publishing: Sheffield, UK, 2005; pp. 46-88.

80. Boström, M.; Klintman, M. Eco-Standards, Product Labelling and Green Consumerism; Palgrave Macmillan: London, UK, 2008.

81. Alberti, F.G.; Giusti, J.D. Cultural heritage, tourism and regional competitiveness: The Motor Valley Cluster. City Cult. Soc. 2012, 3, 261-273. [CrossRef]

(C) 2020 by the authors. Licensee MDPI, Basel, Switzerland. This article is an open access article distributed under the terms and conditions of the Creative Commons Attribution (CC BY) license (http://creativecommons.org/licenses/by/4.0/). 